\title{
Analysis of accessibility from collection and delivery points: towards the sustainability of the e-commerce delivery
}

\author{
Análise da acessibilidade de pick-up points: rumo à sustentabilidade das \\ entregas do comércio eletrônico
}

Leise Kelli de Oliveira[a] (), Renata Lúcia Magalhães de Oliveira[b] (ㄷ,

Luisa Tavares Muzzi de Sousa[a], lan de Paula Caliari[b], Carla de Oliveira Leite Nascimento[a]

[a] Universidade Federal de Minas Gerais (UFMG), Belo Horizonte, MG, Brasil

[b] Centro Federal de Educação Tecnológica de Minas, Belo Horizonte, MG, Brasil

How to cite: Oliveira, L. K., Oliveira, R. L. M., Sousa, L. T. M., Caliari, I. P. \& Nascimento, C. O. L. (2019). Analysis of accessibility from collection and delivery points: towards the sustainability of the e-commerce delivery. urbe. Revista Brasileira de Gestão Urbana, 11, e20190048. https://doi.org/10.1590/2175-3369.011.e20190048

\begin{abstract}
The collection and delivery points (CDP) are an alternative to home deliveries and an important opportunity to reduce failed deliveries within urban areas. In this study, we propose to analyze the accessibility from CDPs located in commercial establishments (drugstores, gas stations, post offices, supermarkets, and malls) considered most attractive by e-consumers to receive this delivery solution. The methodological approach uses spatial analysis to identify the coverage area of the CDPs considering socioeconomic data and e-consumer preferences. Also, spatial tools to analyze the accessibility of CDPs were used, considering the transport infrastructure, the population location, and job opportunities location through different transport modes. The results indicated differences in levels of accessibility between the CDPs, highlighting the important associations among economic activities, land use patterns, and transport to plan for sustainable cities. The use of cluster analysis methods as a methodological approach is one contribution and can be replicated to support decision-making in other cities.
\end{abstract}

Keywords: Urban freight transport. Collection and delivery points. Accessibility. E-commerce delivery. Last-mile delivery.

\section{Resumo}

O pick-up point (PP) é uma alternativa às entregas em casa e uma importante oportunidade para reduzir as entregas fracassadas dentro das áreas urbanas. Neste estudo, propomos analisar a acessibilidade dos PPs localizados em estabelecimentos comerciais (farmácias, postos de gasolina, correios, supermercados e shopping centers) considerados mais atraentes pelos e-consumidores para receber essa solução de entrega. A abordagem metodológica utiliza a análise espacial para identificar a área de cobertura dos PPs considerando dados socioeconômicos e preferências do consumidor eletrônico. Ainda assim, usamos ferramentas espaciais para analisar a acessibilidade dos PPs considerando a

LKO is doctor in Industrial Engineering, associate professor, e-mail: leise@etg.ufmg.br

RLMO is doctor in Geography, associate professor, e-mail: renataoliveira@cefetmg.br

LTMS is civil engineering, e-mail: luisamuzzi29@gmail.com

IPC is transportation engineering, e-mail: iandepaula1995@gmail.com

COLN is civil engineering, e-mail: carla.oln@gmail.com 
infraestrutura de transporte, a localização da população e a localização das oportunidades de trabalho através de diferentes modos de transporte. Os resultados indicam diferenças nos níveis de acessibilidade entre os PPS, destacando as importantes associações entre atividades econômicas, padrões de uso da terra e transporte no planejamento de cidades sustentáveis. $O$ uso de métodos de análise de cluster como abordagem metodológica é uma contribuição e pode ser replicado para apoiar a tomada de decisões em outras cidades.

Palavras-chave: Transporte urbano de carga. Pick-up points. Acessibilidade. Entrega do comércio eletrônico. Entrega da última milha.

\section{Introduction}

Over the last few years, online purchases increased significantly. Latin American citizens use electronic channels less often (9.2 transactions per person per year) than consumers in Asia (22.1 transactions per person per year), North America (19 transactions per person per year) and Europe (18.4 transactions per person per year) (KPMG International Cooperative, 2017). In Brazil, 25.5 million online consumers performed at least one purchase in the first half of 2017 (50 million orders), 10.3\% higher than in 2016 (E-bit, 2017). In addition, in Brazil, home delivery is the main service for e-commerce parcel distribution: $38 \%$ of online retailers ship parcels to consumers with no charge when the purchase is not urgent. In addition, if e-consumers retrieve the products at a physical store, retailers do not charge for transport (E-bit, 2017). E-commerce customers paid BRL 1.03 billion in total freight charges in 2017, resulting in an average of BRL 29.93 per delivery (US $\$ 1 \approx$ BRL 4.0, in October, 2 2018) (E-bit, 2017).

The growth in e-commerce led to an increase of total parcels delivered (Comi \& Nuzzolo, 2016; Guajardar et al., 2016) and therefore, in home deliveries (Visser et al., 2014; Ducret, 2014; Ehmke \& Campbell, 2014; Comi \& Nuzzolo, 2016). However, it is not always possible for the e-consumer to be at home when their parcels are delivered, leading to a significant number of failed deliveries (Song et al., 2009, van Duin et al., 2016; Kedia et al., 2017). Failures in the delivery process are a problem, not only for the buyer, but also for the carrier. Companies spend extra money redelivering parcels and can increase traffic congestion and pollution emissions, and result in other associated externalities (Song et al., 2009; Lachapelle et al., 2018). Since home deliveries present many disadvantages, such as low efficiency and flexibility (Junjie \& Min, 2013; Ehmke \& Campbell, 2014; van Duin et al., 2016), it is necessary to consider alternative delivery methods (Nuzzolo \& Comi, 2014). Thus, a collection and delivery point (CDP) is one interesting alternative as a more convenient and flexible delivery option for customers and companies and one solution to the last-mile delivery problem (McLeod et al., 2006; Xu et al., 2011; Morganti et al., 2014b; Iwan et al., 2016; Oliveira et al., 2017; Allen et al., 2018; Yuen etal., 2018). This solution may also result reduce the number of home delivery failure (McLeod et al., 2006; Kedia et al., 2017), the freight charges for stakeholders, the number of deliveries (due to the consolidation of multiple deliveries in a single point), the number of trips and, consequently, the congestion and emission pollutants (McLeod et al., 2006; Allen et al., 2018), improving the efficiency of the delivery process by reducing fuel and workforce consumption and increases the ratio of successful stops/parcels deliveries (van Duin et al., 2016; Wang et al., 2018). Consequently, this solution contributes to urban freight transport (Kedia et al., 2017; Yuen et al., 2018) and urban mobility sustainability (Lachapelle et al., 2018).

In order to get efficiency and provide sustainability to the system, the location of the CDPs needs to maximise accessibility for potential users. In this case, CDPs near residences and workplaces such as public transport stations, gas stations, post offices, supermarkets, store parking lots or inside of stores are considered good locations (Junjie \& Min, 2013; Lemke et al., 2016; Kedia et al., 2017). In general, the accessibility of CDP, and socio-demographic characteristics are important roles in the success of CDP (Kedia et al., 2017; Lachapelle et al., 2018). 
In this paper, a CDPs system is defined as a network of facilities where carriers deliver orders, and e-customers collect the online purchases as an alternative to home delivery. The CDP shall be located in accessible places in order to promote sustainability to urban freight transport (due to the consolidation of goods in optimized trips) and a sustainable urban mobility (due the e-consumers collect the goods using non-motorized modes).

In this context, we propose to measure the accessibility to the CPDs in commercial establishments considered most attractive by e-consumers to receive this delivery solution. The research approach is based in two steps: the spatial pattern analysis for each establishment category using average nearest neighbour distance, and the accessibility levels to the CDPs through service area within specific thresholds. We validate the method carrying out the analysis for Belo Horizonte (Brazil) and use information about online customers' preferences, socioeconomic data, transportation infrastructure, and the commercial establishments' characteristics. The accessibility is measured considering the CPDs located in drugstores, gas stations, post offices, supermarkets, and malls.

\section{Theoretical basis}

The scholars consider different approaches and methods to analyse CPDs systems (Song et al., 2009), for instance: environmental benefits (Edwards et al., 2010; Song et al., 2013; Liu et al., 2019), system dynamics models (Oliveira et al., 2010), scenario analysis of e-grocery distribution (Durand \& Gonzalez-Feliu, 2012), modelling and simulation of e-commerce distribution (McLeod et al., 2006; González-Felíu et al., 2012), location analysis (Morganti et al., 2014a; Lemke et al., 2016), attitudes and behavioural analysis (Junjie \& Min, 2013; Ducret, 2014; Xiao et al., 2018), e-consumers preferences (Moroz \& Polkowski, 2016; Kedia et al., 2017; Oliveira et al., 2017; Beckers et al., 2018; Lachapelle et al., 2018; Yuen et al., 2018; Wang et al., 2018), and parcel locker facilities location problem (Deutsch \& Golany, 2017).

Firstly, when shopping online, the e-consumers can choose to receive the goods at home or collect in a CDP. If a CDP is chosen, the "[...] parcel is shipped to a partner shop or business, which then hands it over to the end-customer [...]" (Borsenberger et al., 2014, p. 76). After the consumer makes the purchase and chooses a CDP according to their perceived convenience (near home, work, or on the way from home to work, for instance), the carrier delivers the parcels to the assigned place. The e-customer receives an e-mail or SMS notifying of the package arrival and pickup deadline. The CDPs system can be manned or unmanned. A manned CDPs system can also be called 'click and collect systems' (Lockie, 2014) or 'service point' (Kedia et al., 2017). An unmanned CDPs system can also be called 'locker points' (Kedia et al., 2017), 'pickup points' (Morganti et al., 2014b), 'automated lockers network' (Morganti et al., 2014b), 'parcel lockers' (Iwan et al., 2016; Vakulenko et al., 2018), 'automatic delivery stations' (Oliveira et al., 2017), 'automated parcel stations' (Wang et al., 2018). The type of CDPs system (assisted or unassisted) could be chosen by interested (commercial establishments, couriers or operators) according to their goals.

In France, CDPs are already consolidated as an alternative method to deliver parcels. In this country, urban and rural areas have express access to those facilities, and more than $20 \%$ of e-commerce shipments regularly use this delivery option (Morganti et al., 2014b). The French companies Mondial Relay, Relais Colis, Kiala, and Pickup Services contributed to this use by offering access to a delivery point to $90 \%$ of the population within a 10-minute walk or car drive (Morganti et al., 2014b).

In Germany, the number of e-commerce shoppers increased in the last few years (Morganti et al., 2014b). Germans' online shopping habits present a unique characteristic that increased the number of deliveries: people only pay for the items bought online once they are certain they will keep them after they receive the order. Therefore, customers usually purchase many items of different colours and sizes, pay for the ones they like, and return the others (Morganti et al., 2014b). This habit contributed to the growth of freight transportation flows and its externalities. Almost $90 \%$ of e-consumers in Germany 
choose home delivery, even though CDPs already exists (Morganti et al., 2014b) with an average distance in urban areas of the 600 meters. In rural areas, this average distance is three kilometres. Thus, $90 \%$ of Germany's population has access to an automated CDP within a 10-minute walking distance from their homes (Morganti et al., 2014b). The CDPs are located in shops, and 70\% of the parcels are collected within 24 hours (Morganti et al., 2014b).

In Poland, online orders have been increasing steadily. Nevertheless, there is a fragmentation in the delivery system because customers purchase a small number of products and want fast deliveries (Iwan et al., 2016). The InPost Company implemented parcel lockers that are available 24 hours per day, seven days a week. Customers have three days to pick up the order once it arrives in the locker, and the automated stations are placed in monitored sites such as gas stations and supermarkets to ensure the users' safety. The machines have cameras and alarms installed (Iwan et al., 2016). The e-consumers expect that the lockers will be near their homes, on the way from work, and close to parking spaces (Iwan et al., 2016).

Despite the different methods to analyse CDPs, we identify few academic papers focusing on accessibility analysis of the CDP system. In general, the academic studies focus on the design of implementation plans or the e-consumers preferences to use these systems. Thus, in this paper, we enhance Morganti et al. (2014a) method by adding e-consumers' preferences (Lemke et al., 2016), and socio-demographic characteristics (Kedia et al., 2017; Lachapelle et al., 2018) to analyse the spatial pattern and accessibility of CDPs.

\section{Research approach}

We designed the research approach in two steps: (i) analysis of the spatial patterns of CDPs, and (ii) analysis of the accessibility to the CDPs. We detail each step below.

\section{Step 1: Spatial patterns of the CDPs}

In this step, we calculated the Kernel Density to determine the concentration of CDPs. We identified the density (point features) around each generated raster cell considering a kernel function to fit a surface. We considered the CDPs located within the circular neighbourhood perimeter determined by the selected radius in the density calculation. In our approach, we assume a 1,000-meter search radius to generate the raster for every CDP.

We utilised the 'average nearest neighbour distance' to analyse the spatial pattern of CDPs, giving measures of the distance between each point feature and its nearest neighbour. We considered the Manhattan Distance to determine the distances between locations, resulting in a more similar method to represent urban displacements. If the average distance is lower than the average for a hypothetical random distribution, the data present a clustered spatial structure. On the other hand, if the average distance is higher than the hypothetical random distribution, the data present a dispersed spatial structure. We used the $\mathrm{z}$-score and the $\mathrm{p}$-value to validate the results. If the z-score and p-values are not significant, then the spatial pattern occurs by random chance (Langley \& Iba, 1993).

In order to identify the relationship between the location and socio-economic variables, we propose the indicator called InPop composed of the product of the average monthly household income and the population for each neighbourhood. Neighbourhood with a high combination of population and income are those with potential e-consumer demand (Oliveira et al., 2017; Beckers et al., 2018), referring to as high income-population areas.

In addition, we identified the number of job opportunities in each neighbourhood. CDPs located near peoples' residences and close to the workplace have more potential of usage (Junjie \& Min, 2013; Iwan et al., 2016; Kedia et al., 2017). The relationship between the location and job opportunities could 
indicate potential places to allocate the CDPs. This analysis was based on a Hot Spot Analysis tool. We evaluated the Z-scores $(>1.0)$ and p-values $(<0.05)$ to identify if the data is clustered spatially for high or low values (Esri, 2012).

Furthermore, we created a 500-meter buffer from the street network to identify the number of establishments closer to the main roads and with accessibility to possible CDPs. We calculated the number of these establishments located within the influence area of the road transportation infrastructure. For this analysis, we assumed that the more accessible CDPs should be located within the buffer.

\section{Step 2: Analysis of the accessibility by the CDPs}

In this step, we calculated the network service area to measure the accessibility to the CDPs. A network service area is a region derived from a particular location considering all roads that can be reached within the specified impedance (time or distance). Once the service areas are determined, it is possible to determine the number of people within this region. We used the Network Analyst extension in ArcMap 10.3 to generate service areas.

We calculate the number of people considering three different area ranges related to the maximum distance acceptable by e-consumers to reach the goods using different transport modes.

\section{Study area and data}

We carried out an analysis to Belo Horizonte (Brazil), the sixth-largest urban area in terms of population in Brazil. Belo Horizonte has the fifth-largest GDP among Brazilian cities and had a motorized population of 1,907,891 vehicles (69\% cars, $15.2 \%$ light freight vehicles, $13 \%$ motorcycles, $2 \%$ heavy freight vehicles, and $0.8 \%$ buses) in December 2017, resulting in a motorization index of 1.31 inhabitants per vehicle (Denatran, 2018). We present the location of Belo Horizonte in Figure 1.

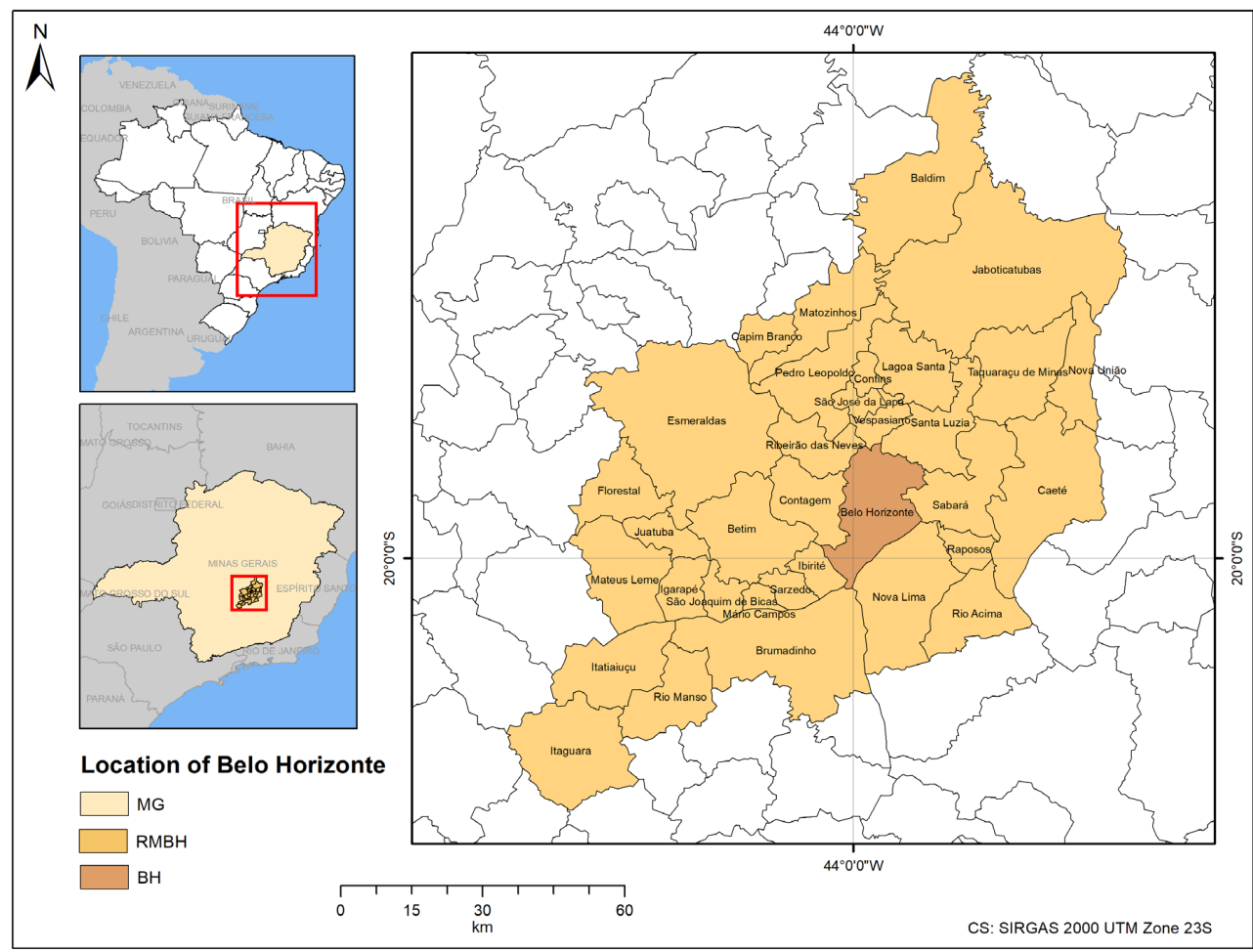

Figure 1 - Belo Horizonte location. Source: The authors. 
We obtained e-consumers' profiles and preferences for the potential use of a CDPs system in Belo Horizonte from Oliveira et al. (2017): 72\% of the respondents live in households located in districts with an average monthly income that varies from $\mathrm{R} \$ 2,202.99$ to $\mathrm{R} \$ 9,029.35$ (US\$1 $\approx \mathrm{R} \$ 4$, in October, 2 2018). These households contain a high-income population. Additionally, $63 \%$ of the respondents stated that they would pick up their parcels at CDPs if they were implemented in Belo Horizonte.

As there are no CDPs in Belo Horizonte, we assume supermarkets, shopping malls, drugstores, gas stations, and post office as potential places to install CDPs. We collected data and locations for these establishments and the establishment database is composed of 128 drugstores, 52 gas stations, 73 post offices, 18 supermarkets, and 30 malls. We also acquired information about the availability of parking spaces and operating hours for each establishment, since those are important attributes according to Lemke et al. (2016).

According to Oliveira et al. (2017), respondents would mainly go on foot and use private vehicles to collect their parcels. Considering an average speed of $1.4 \mathrm{~m} / \mathrm{s}$ for pedestrians (Garber \& Hoel, 2014) and $10 \mathrm{~m} / \mathrm{s}$ for urban car displacement (Newman \& Kenwothy, 1999), we calculate the acceptable distance for CDPs' users for each transport mode presented in Table 1. We included long travel time (45 minutes and 60 minutes) due the average travel time in Belo Horizonte is 35 minutes (all modes), 62 minutes by public transportation and 32 minutes by private car (Agência de Desenvolvimento da Região Metropolitana de Belo Horizonte, 2012).

Table 1 - Travel times and maximum distances considering displacements on foot and by car

\begin{tabular}{ccccc}
\hline Maximum travel time to reach the CDPs & On Foot \% & By car \% & Maximum distance on foot & Maximum distance by car \\
\hline Up to 5 min & 55 & 48 & 420 meters & 3,000 meters \\
Up to 15 min & 70 & 61 & 1,260 meters & 9,000 meters \\
Up to 30 min & 95 & 93 & 2,520 meters & 18,000 meters \\
Up to 45 min & 99 & 99 & 3,780 meters & 27,000 meters \\
Up to 60 min & 100 & 100 & 5,040 meters & 36,000 meters \\
\hline
\end{tabular}

Source: Based on Oliveira et al. (2017), Garber \& Hoel (2014) and Newman \& Kenwothy (1999).

Concerning the maximum distance on foot and by car, we considered three different ranges $(1,000$, 2,000 and 5,000 meters in the network) for each CDPs (we consider each establishment as one CDP) as the maximum distances acceptable by pedestrians and drivers. Of the respondents, $70 \%$ are willing to walk up to 1,000 meters (up to 15 minute-walk) and $95 \%$ of pedestrians and $48 \%$ of car drivers would agree to collect their goods within 2,000 meters (30 minutes or less). Finally, 52\% of car drivers are willing to travel up to 5,000 meters to retrieve purchased goods in CDPs. We recognise that these threshold distances differ from those stated in the literature (e.g., Morganti et al., 2014a). However, these limits are more representative of the Brazilian reality.

We collected the data on the average monthly household income and population from the census (IBGE, 2010). Additionally, we gathered information about the location of job opportunities from the municipal register of taxpayers of Belo Horizonte (2016).

\section{Results}

We assume that the CDPs should be located in one establishment in operation due to the fact that there is no consolidated CDPs network in Brazil. Bearing in mind this assumption, we present the results according to the two steps of the methodological approach: (i) spatial pattern analysis of the CDPs, and (ii) accessibility level to the CDPs. 


\section{Spatial pattern of the CDPs}

Figure 2 illustrates the location of establishments, considering the availability of parking spaces and operating hours. The availability of parking spaces is an important attribute for potential sites according to consumers' preferences. In Belo Horizonte, $67 \%$ of establishments offer parking spaces for customers (Figure 2a). Still, $10 \%$ of these establishments have a 24 -hour time-window, but $54 \%$ stay open from 14 to 18 hours a day, and the other $36 \%$ have a time-window of up to 13 hours a day, meeting customers' preferences (Figure $2 \mathrm{~b}$ ). This information indicates that e-consumers will face little impedance regarding these attributes to reach their purchased goods if this network of establishments constitutes the CDPs system in Belo Horizonte.

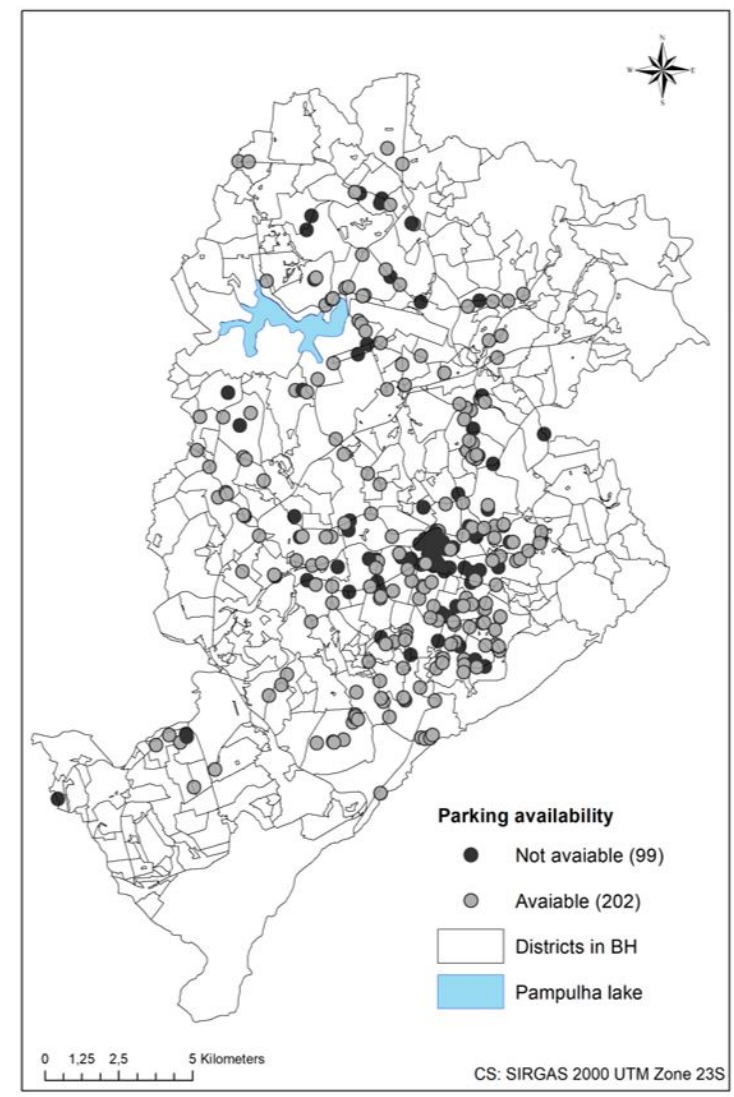

(a) availability of parking spaces

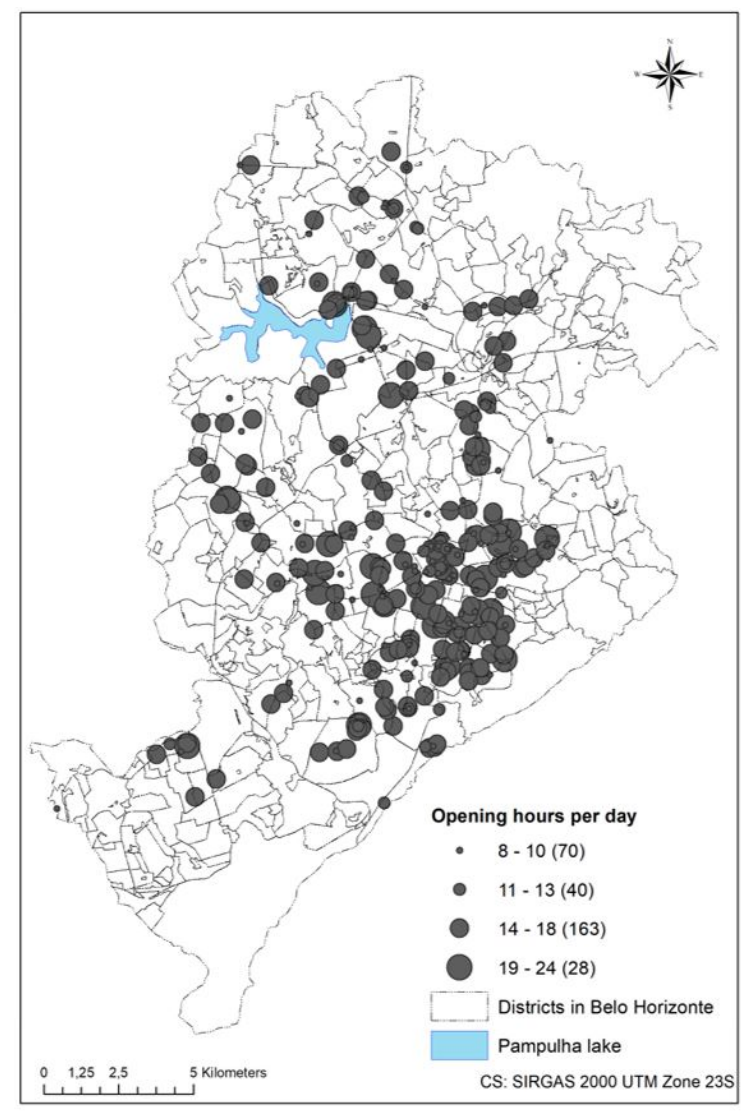

(b) operating hours

Figure 2 - Location of CDPs: availability of parking spaces (a) and operating hours (b). Source: The authors.

We consider areas with high income-population and job concentration (clusters with statistical significance) to analyse the spatial pattern of the CDPs in Belo Horizonte. We present these results in Figure 3. We highlight the significant overlapping in the residential concentration of high income-population and job opportunities in the central business district (CBD) of Belo Horizonte (planned area). The clustered area of high income-population is $42.4 \mathrm{~km}^{2}$ and the clustered area of job opportunities is $17.3 \mathrm{~km}^{2}$. Additionally, the area of intersection between these two areas is $11.2 \mathrm{~km}^{2}$. Thus, $65 \%$ of the clustered area of job opportunities overlaps with the high income-population. Therefore, this superimposed area congregates a significant portion of the potential demand (residences and workplaces) and might be adequate for the location of CDPs. 


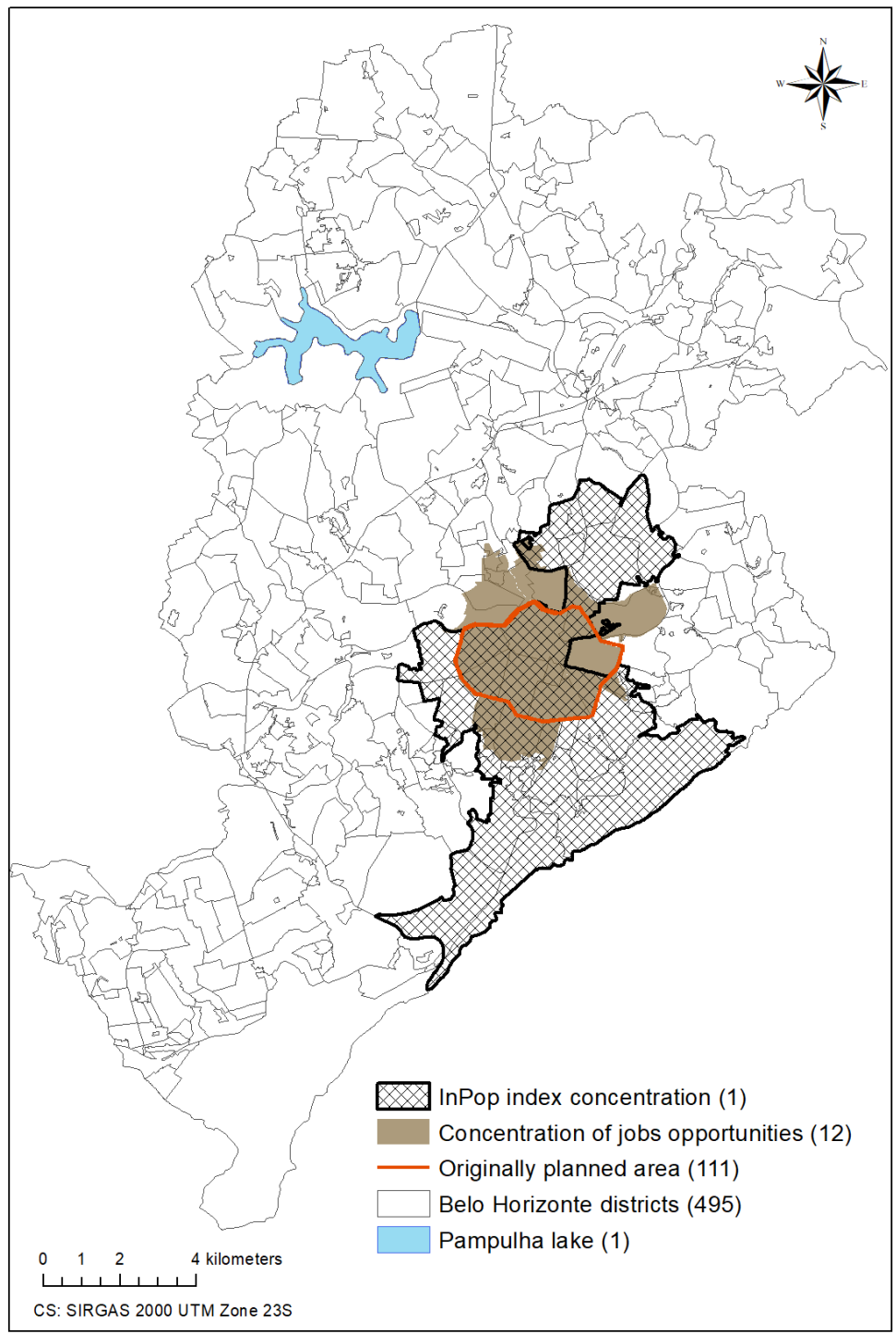

Figure 3 - Concentration of high-income population and job opportunities in Belo Horizonte (Getis-Ord Gi* cluster analysis). Source: The authors.

Figure 4 presents the overlapping spatial analysis considering the income-population and job opportunities (Getis-Ord Gi* cluster analysis) and the spatial concentration of the establishments. We observe a spatial concentration of establishments within the clustered districts with high InPop and job opportunities for drugstores, and malls. Conversely, we observe a linear distribution of gas stations along the main roads, which we verify later, resulting in less spatial overlap between the concentration of income-population and job opportunities and these establishments. The supermarkets present a spatial concentration with high-income population areas and a linear distribution in some of the main corridors of Belo Horizonte considering job opportunities. Finally, we identify a disperse distribution of post offices, disregarding the location of high income-populations and job opportunity clusters. These results imply that, from an investor viewpoint, the locations of drugstores and malls have a spatial pattern more suitable to CDPs because they are closer to high income-population and job opportunities. Additionally, we also present in Figure 4 the density of establishments within a maximum distance of $500 \mathrm{~m}$ from the main road corridors in Belo Horizonte. 

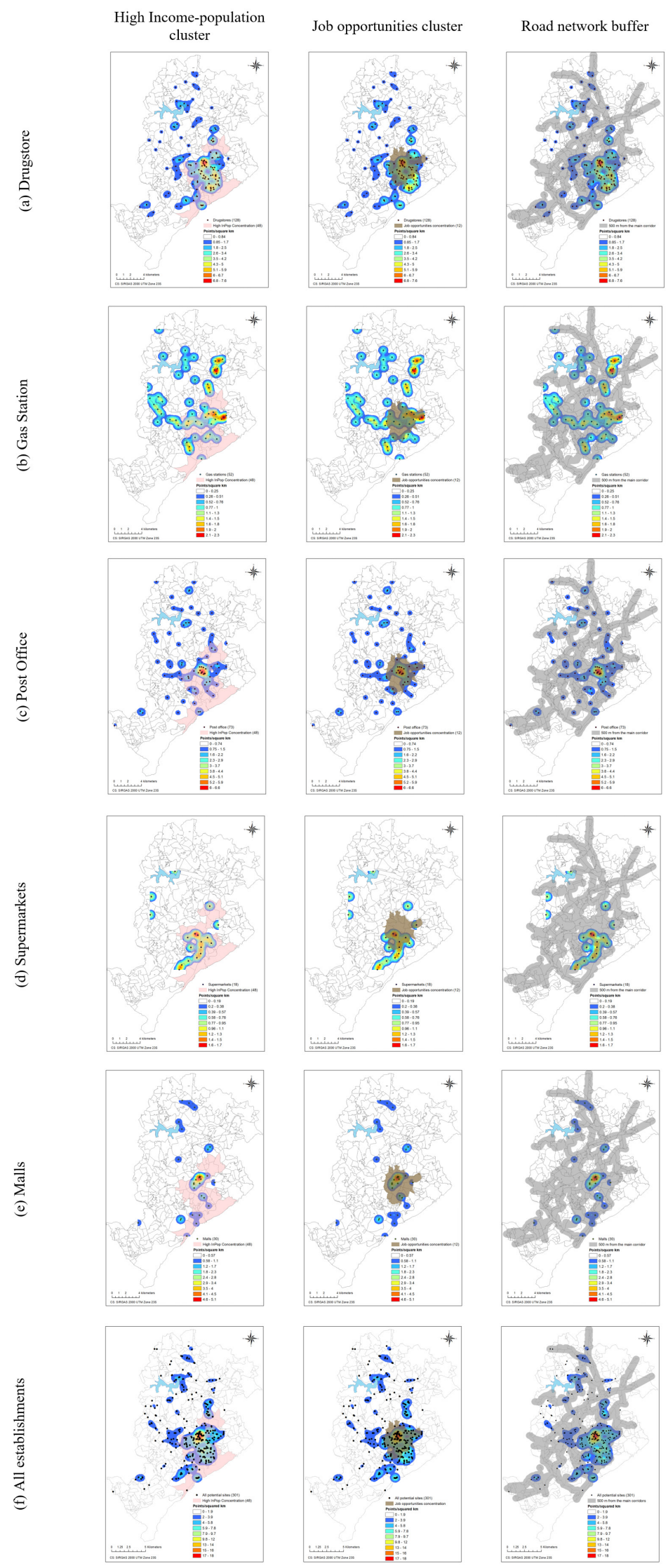

Figure 4 - High income-population, job opportunities (Getis-Ord Gi* cluster analysis), 500-meter buffer of main corridors and the spatial concentration of establishments (Kernel Density). Source: The authors. 
We quantify the number of establishments located within (i) the high income-population areas, (ii) the job opportunities areas, and (iii) establishments located in the 500-meter buffer from the main corridors, in order to determine the intensity of the overlap of the assessed attributes (Table 2). The results indicate that supermarkets $(61.1 \%)$, malls $(60.0 \%)$, and drugstores $(51.6 \%)$ are more concentrated in high income-population areas (the most desirable situation according to Oliveira et al., 2017). The areas with a higher concentration of drugstores overlap with the job opportunities clustered area. Finally, all commercial segments are closer to the main corridors of Belo Horizonte. In a general analysis, we conclude that drugstores present a spatial pattern that overlaps high income-population, job opportunities clustered areas, and are closer to the main corridors, being the most attractive segment to CDPs. Nevertheless, the number of stores is the most expressive among the retailers analysed that result in this spatial structure.

Table 2 - Number and percentage of commercial establishments within the clustered areas of high incomepopulation areas, job opportunities areas, and main corridor buffer

\begin{tabular}{ccccccccc}
\hline \multirow{2}{*}{ Segments } & $\begin{array}{c}\text { Number of } \\
\text { establishments }(\mathbf{a})\end{array}$ & $\begin{array}{c}\text { High income- } \\
\text { population }\end{array}$ & \multicolumn{2}{c}{ Job opportunities } & \multicolumn{2}{c}{ Main corridors } \\
\cline { 3 - 9 } & 128 & 66 & 51.6 & 37 & 28.9 & 91 & 71.1 \\
\hline Drugstores & 52 & 14 & 26.9 & 12 & 9.4 & 38 & 73.1 \\
Gas Stations & 73 & 32 & 43.8 & 23 & 18 & 53 & 73.0 \\
Post Offices & 18 & 11 & 61.1 & 6 & 4.7 & 11 & 61.1 \\
Supermarkets & 30 & 18 & 60.0 & 13 & 10.2 & 26 & 86.7 \\
Malls & 301 & 141 & 46.8 & 92 & 30.6 & 266 & 88.4 \\
\hline
\end{tabular}

Source: The authors.

Finally, the spatial pattern for each segment (Table 3) was identified. Drugstores present an agglomeration of establishments in specific areas of Belo Horizonte (clustered pattern) closer to income-population and job opportunities areas, corroborating the findings in the previous analysis. Supermarkets and gas stations present a spatially scattered structure (dispersed), which indicates that the location decision might have been based on the proximity to transit and road access. Finally, malls and post offices present random spatial pattern indicating that the locational decision for these segments might have considered the spatial coverage.

Table 3 - Average Nearest Neighbour Distance Analysis

\begin{tabular}{cccc}
\hline Segment & \multicolumn{3}{c}{$\begin{array}{c}\text { Average Nearest Neighbour } \\
\text { (Manhattan distance) }\end{array}$} \\
\cline { 2 - 4 } & z-score & p-value & Spatial Pattern \\
\hline Drugstores & $\mathbf{- 3 . 6 1}$ & $\mathbf{0 . 0 0 0 3 1}$ & Clustered \\
Gas Stations & $\mathbf{3 . 7 0}$ & $\mathbf{0 . 0 0 0 2 2}$ & Dispersed \\
Malls & 0.52 & 0.60636 & Random \\
Post Offices & 1.62 & 0.10515 & Random \\
Supermarkets & $\mathbf{4 . 7 3}$ & $\mathbf{0 . 0 0 0 0 0}$ & Dispersed \\
All establishments & $\mathbf{- 1 0 . 5 0}$ & $\mathbf{0 . 0 0 0 0 0}$ & Clustered \\
\hline
\end{tabular}

Source: The authors. 


\section{Accessibility to the CDPs}

We generated service areas for each commercial segment and calculated the number of people to measure the population coverage of each CDPs. We considered three different ranges presented in Table 1: a 1,000-meter range that can be reached on foot, a 2,000-meter range can be reached both on foot or by car, and 5,000-meter range that can be reached by car. We show the service areas for each commercial segment in Figure 5 and the quantitative analysis in Figure 6.

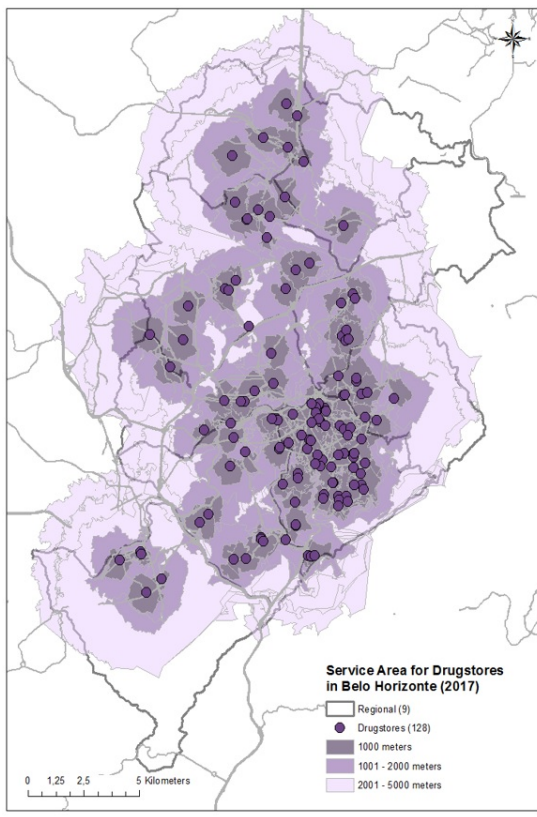

(a) Drugstores

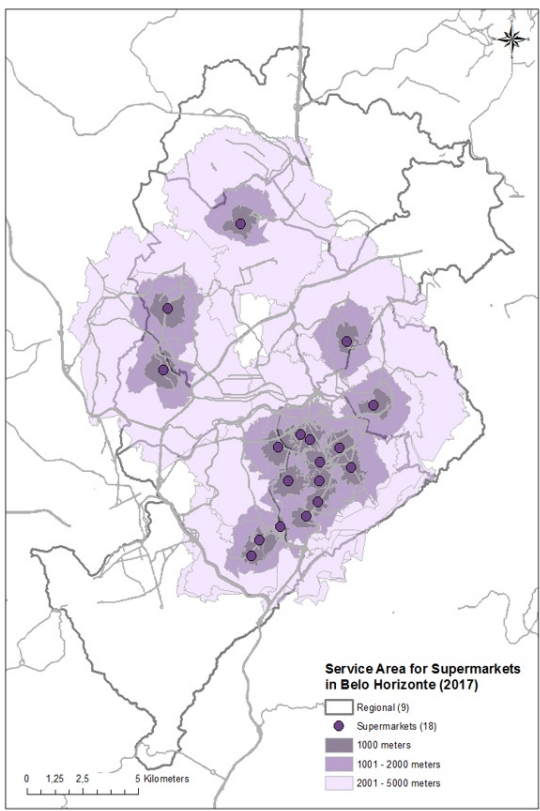

(d) Supermarkets

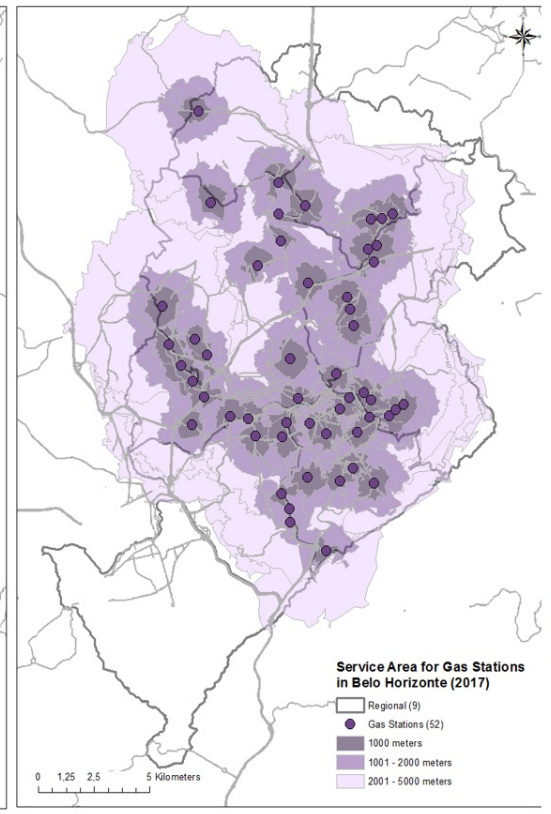

(b) Gas station

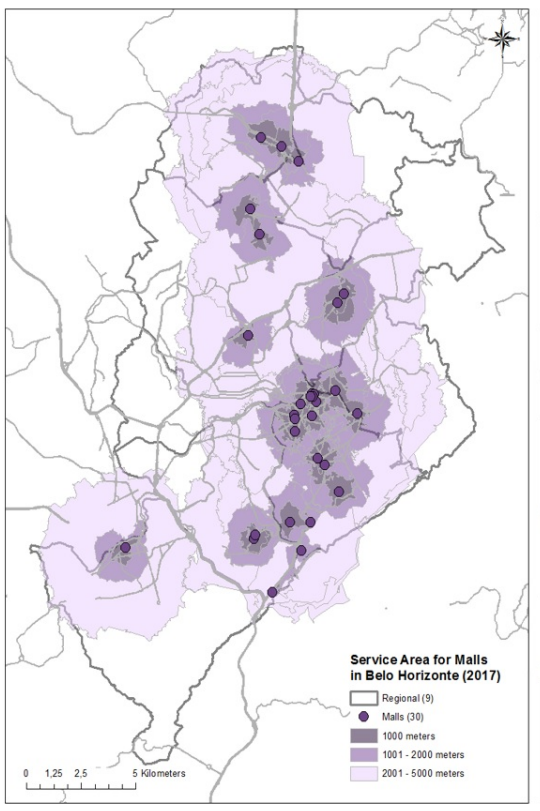

(e) Malls

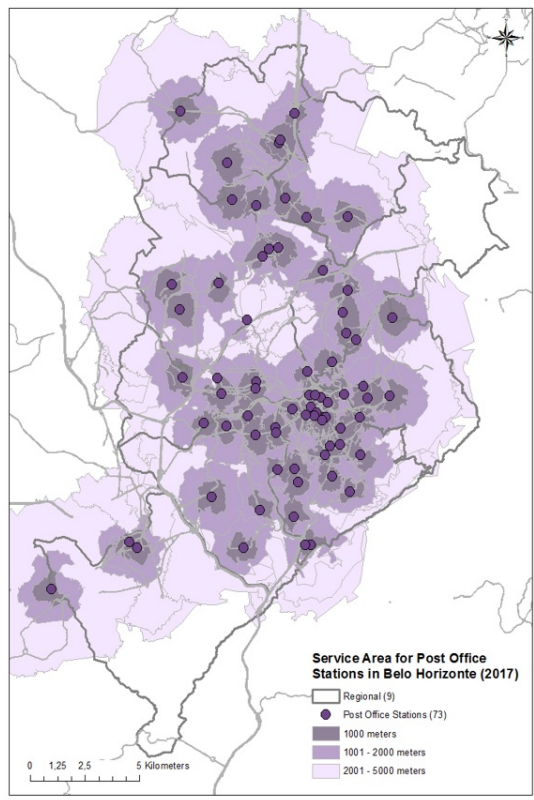

(c) Post Office

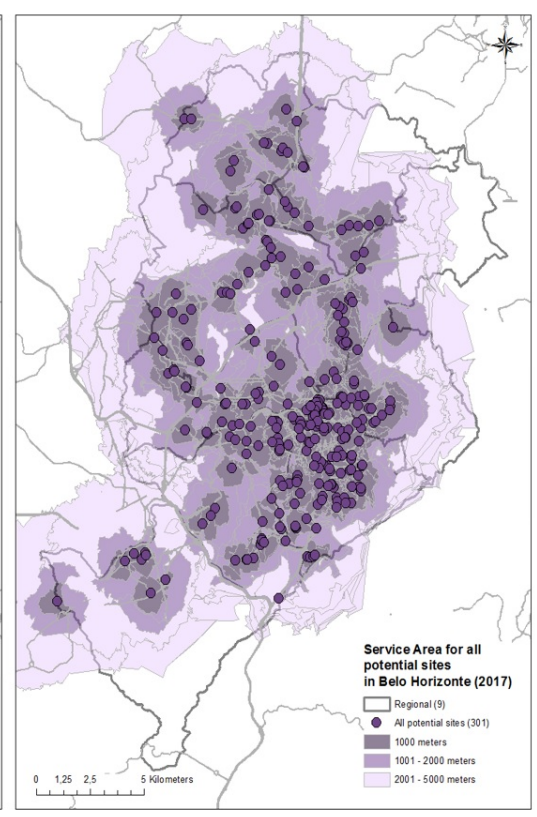

(f) All establishments

Figure 5 - Service area of establishments. Source: The authors. 


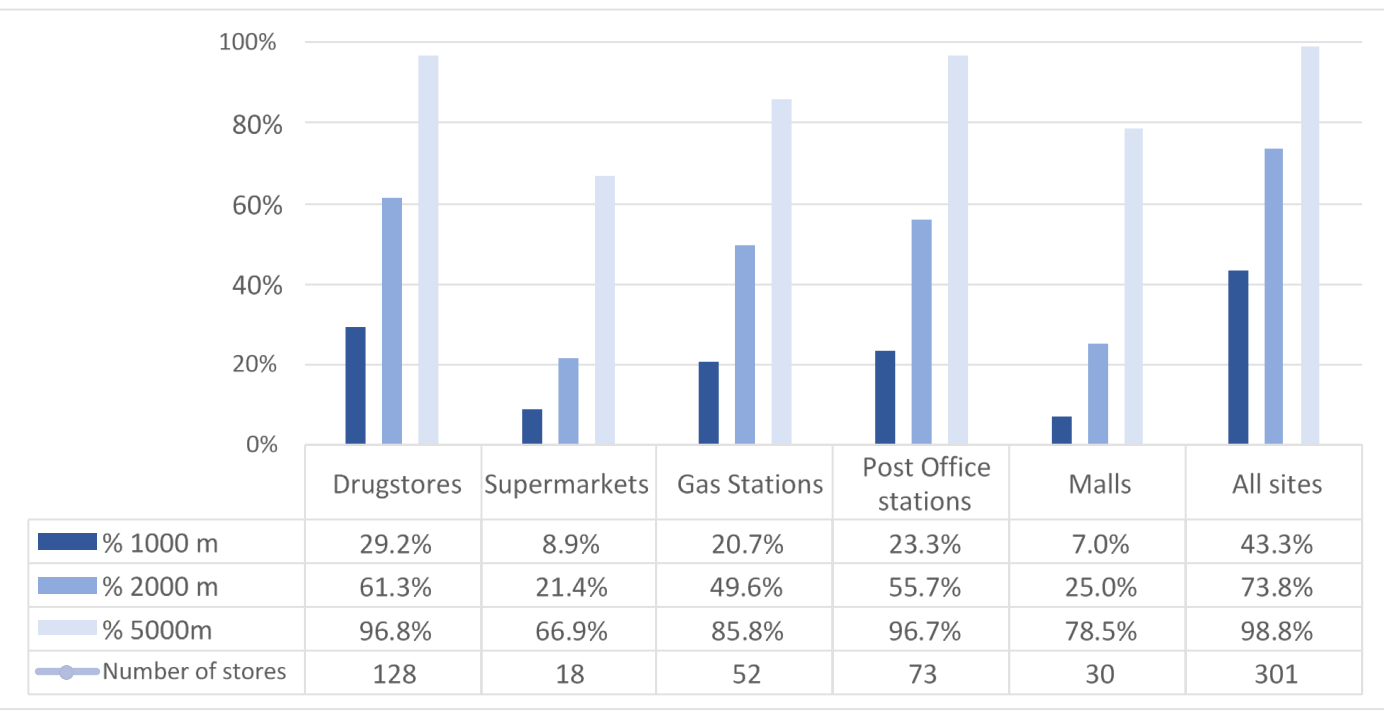

Figure 6 - Percentage of the population by each service area range and type of establishment. Source: The authors.

The results indicate that drugstores, gas stations, and post offices have the potential to serve a more significant portion of the population in Belo Horizonte: $29.2 \%$ of the total population of Belo Horizonte is located up to 1,000 meters from drugstores, $20.7 \%$ is located up to 1,000 meters from gas stations, and $23.3 \%$ live within 1,000 meters of post offices. Therefore, we conclude that drugstores, gas stations, and post offices can stimulate e-consumers to retrieve their purchased goods on foot if the CDPs are located in these establishments. In the same way, drugstores and post offices can serve up to $96.8 \%$ and $96.7 \%$ of residents, respectively (Belo Horizonte) if consumers travel by car.

\section{Discussion}

Table 4 summarises the results: Drugstores are concentrated in high income-population and job opportunities areas. Due to the large number of drugstores (128) compared to the other segments, it serves a considerable share of the Belo Horizonte population. Drugstores are mostly located in the surroundings of the main corridors of Belo Horizonte, indicating better access for drivers to retrieve goods in CDPs located in these establishments. Thus, the government should encourage the installation of CDPs in drugstores by developing policies that could support the investment and operating costs of the system. Additionally, this network can provide more equitable spatial coverage of the population of Belo Horizonte, disregarding socioeconomic characteristics.

Table 4 - Results summary (*without statistical significance)

\begin{tabular}{cccccc}
\hline Attributes & Drugstores & Gas Stations & Post Offices & Supermarkets & Malls \\
\hline High income-population & high & low & low & high & high \\
Job opportunity & high & low & medium & low & medium \\
Population & high & medium & high & low & low \\
Main road & high & high & high & high & high \\
Number of establishments & very high & medium & high & low & low \\
Spatial pattern & clustered & dispersed & $*$ & dispersed & $*$ \\
Viewpoint decision-making & Public & Public or & Public & Private & Private \\
\hline
\end{tabular}

Source: The authors. 
Post offices present similar results regarding the number of establishments and spatial pattern. The location of the post offices also accounts for proximity to the main corridors of the city (good access for drivers and transit users). Thus, installing CDPs in post offices may be interesting from the public point of view, when equitable access to these facilities is the main goal.

The location of the supermarkets also overlaps with the high income-population clustered area and main corridors, but the spatial coverage is high as the ones discussed before. This location indicates a predominance of establishments to serve local consumers closer to their residences and with a propensity for non-motorized access to reach goods. These aspects indicate that CDPs in supermarkets should be considered from a private perspective. Similarly, shopping malls should consider this private perspective.

Finally, the location of gas stations presents an equilibrium concerning the number of establishments, location of e-consumers served, and proximity to the main roads of Belo Horizonte. Therefore, gas stations can be interesting locations for CDPs, from the private and the public perspective.

The results have convergence with the literature. Drugstores and post offices are located in places with high population density, as Morganti et al. (2014a), Iwan et al. (2016), Lemke et al. (2016), and Lachapelle et al. (2018) point out. In addition, Iwan et al. (2016), Lemke et al. (2016), and Lachapelle et al. (2018) point out that a gas station could be a good location to install CDPs. In Szczecin (Poland), locating lockers close to shopping centres increased the number of parcels significantly each month (Iwan et al., 2016). The results indicate potential demand for this solution because shopping malls are located in areas with high income-populations and close to main corridors.

Yet the choice of just one segment could make a CDPs network in Belo Horizonte feasible. This network could stimulate other business to provide these services, and the coverage area of CDPs would reach a broader share of the population. For this, drugstores are a good option in terms of the concentration in high income-population and job opportunities areas, and their proximity to main corridors, providing good access to e-consumers to these facilities. In addition, gas stations are another starting option to locate CDPs considering parking, as Lemke et al. (2016) and Lachapelle et al. (2018) points out.

We also find the CDPs will be accessible for $98.8 \%$ of the population if we consider all 301 establishments. If we consider only sites at a maximum distance of 1,000 meters from homes, the CDPs will be accessible for $43.3 \%$ of the population. However, it is possible to reach $96.8 \%$ of the population with a network in 128 drugstores $(29.2 \%$ up to 1,000 meters) or $96.7 \%$ if the CDPs were located in the 73 post offices $(23.3 \%$ up to 1,000 meters). These results indicate that it is possible to optimise the network to reach more e-consumers with fewer establishments. However, if the aim is to stimulate sustainable mobility, a high number of establishments could encourage non-motorized trips to reach the goods at CDPs.

Finally, even though there are local specificities regarding the placement effectiveness of CDPs in the commercial establishments we have analysed in this study, e-commerce costumers in Latin-American cities could have the same behaviour perceived in other countries. Other facilities, such as public transportation stations, could be considered for this analysis in cities where security is not a problem. Nevertheless, the research approach proposed in this paper considers the interests of private business: attracting people to stores creates more potential consumers while performing a more sustainable urban freight transport. Furthermore, the basic assumption that the analysis should focus on non-motorized trips makes it possible to reduce home deliveries and car trips to retrieve the goods. In the Brazilian case, car dependence is an important issue, and a CDPs network must not generate extra-motorized trips. For this, the stations need to be located in places with high population concentration. 


\section{Conclusion}

The CDP is an alternative to reduce the externalities and extra costs to companies with recurrent failure in home deliveries. In addition, a large number of home deliveries implies more freight traffic, hence more pollution and congestion.

A network covering all urban areas is necessary to stimulate the use of CDPs, as Morganti et al. (2014a) points out. Product-related legislation, vehicle operating laws, and urban land use planning are imperative. In Brazil, CDPs systems have not been thoroughly explored yet. Still, a CDPs system has been proposed as a solution to minimise the externalities of urban freight transport in the Urban Freight Mobility Plan in Belo Horizonte (Belo Horizonte, 2017), but no facilities are operational yet.

In this paper, we analysed the spatial pattern and the accessibility to CDPs located in establishments. We used spatialized socioeconomic, along with e-consumers' preferences, to determine the service area of different commercial segments. We also evaluated the proximity among commercial establishments and the main transportation corridors. We conducted this analysis for Belo Horizonte (Brazil).

Concerning the segments analysed in this paper, supermarkets and malls present a spatial pattern that provides access for the high income-population and is less costly for investors due to the lower number of CDPs to address the demand. In this case, private developers, willing to implement CDPs in these establishments, should establish partnerships with transport companies/e-shops to invest in this solution and deliver e-commerce products in these establishments, offering a 'click and collect' service.

Conversely, post offices and drugstores present a spatial pattern that covers almost all of the city's population. The Brazilian Post is a public company and could install CDPs as a way to reduce home deliveries and, in the same way, create a culture in which e-consumers collect their goods in the points located in post offices. In this case, it is crucial to extend the working hours to meet the desires of potential e-consumers.

In addition, drugstores overlap with the high income-population area, job opportunities area, and main transportation corridors, along with the broader spatial coverage among the sectors investigated. Due to the high number of drugstores and the proximity to residences and workplaces, the potential e-consumers may prioritise non-motorized modes of transportation, contributing to sustainable mobility. The government could also stimulate the location of DCPs in drugstores with policies to support the investment and operational cost.

Furthermore, CDPs in drugstores and supermarkets can take in new customers drawn by the need to collect their parcels. This behaviour can strengthen the commercial activity in these retailers. Instead of longer trips to perform ordinary urban functions in the CBD, the population can develop new habits by traveling shorter distances and using non-motorized transport to accomplish these functions near their homes.

In terms of the research approach, the spatial analysis proved to be a thought-provoking approach to support locational decision-making by analysing the area served by the CDPs system. The proposed methodological approach allows both: (i) the analysis of the spatial structure of the stores in each network; and (ii) a preliminary measurement of the level of accessibility concerning a feasible threshold determined by the consumer. Nevertheless, the accessibility measure considered is business-oriented and does not reflect the potential accessibility or the decision process in the measurement of the accessibility levels for the consumers. We, therefore, suggest further investigation concerning: (i) more consumer-oriented measuring of accessibility levels; and (ii) the investigation of the impacts of the build environment on the levels of accessibility to the CDPs. These approaches, in an integrated analysis, may result in a more comprehensive and effective analysis of the CDPs as last mile solutions.

Despite local specificities, implying that, for instance, the behaviour of e-consumers should be investigated on-site to identify the type of potential establishment for CDPs, this approach can be replicated for different geographical contexts.

Furthermore, to make the locational decision regarding last mile solutions, such as the placement of CDPs, it is necessary to check for spatial heterogeneity in terms of social and economic concentration. In 
Brazil, cities have low-income areas physically connected to high-income areas. Therefore, it is impossible to assess the spatial concentration of the potential market only considering the population. For this, we designed the indicator InPop, which is the product of the average monthly household income and the population within each spatial unit. The results of the analysis of InPop indicate that this is an adequate approach to assess the concentration of socioeconomic attributes when there is spatial heterogeneity. Also, the measures of coverage and distance allowed us to measure the level of accessibility for the CDPs, regarding a business-oriented approach.

Finally, another contribution for local analysis of urban areas with no spatial homogeneity is the use of cluster analysis methods. Assessing the location of establishments or human activity may not provide insights into land use patterns. Clustering techniques proved to be a suitable means to support the analysis of gathered urban phenomena. Furthermore, we relate businesses to the respective territorial context in this study by spatially matching the location of establishments and the clustering of the population and job opportunities. This approach can be replicated to support decision-making regarding city logistics solutions in other cities.

\section{References}

Agência de Desenvolvimento da Região Metropolitana de Belo Horizonte. (2012). Origin and destination survey 2012. Belo Horizonte: Agência de Desenvolvimento da Região Metropolitana de Belo Horizonte. Retrieved in 2019, 4 March, from http://www.agenciarmbh.mg.gov.br/mobilidade-rmbh-2/

Allen, J., Piecyk, M., Piotrowska, M., McLeod, F., Cherrett, T., Ghali, K., Nguyen, T., Bektas, T., Bates, O., Friday, A., Wise, S., \& Austwick, M. (2018). Understanding the impact of e-commerce on last-mile light goods vehicle activity in urban areas: the case of London. Transportation Research Part D, Transport and Environment, 61, 325-338. http://dx.doi.org/10.1016/j.trd.2017.07.020.

Beckers, J., Cárdenas, I., \& Verhetsel, A. (2018). Identifying the geography of online shopping adoption in Belgium. Journal of Retailing and Consumer Services, 45, 33-41. http://dx.doi.org/10.1016/j.jretconser.2018.08.006.

Belo Horizonte. (2016). Municipal register of taxpayers of Belo Horizonte [Database]. Belo Horizonte.

Belo Horizonte. Prefeitura Municipal. (2017). Política de logística urbana de Belo Horizonte. Belo Horizonte: Prefeitura Municipal. Retrieved in 2019, 4 March, from https://prefeitura.pbh.gov.br/bhtrans/cargaurbana/politica-de-logistica-urbana

Borsenberger, C., Cremer, J., De Donder, P., Joram, D., \& Lécou, S. (2014). Pricing of delivery services in the ecommerce sector. In M. A. Crew \& T. J. Brennan (Eds.), The role of the postal and delivery sector in a digital age (pp. 75-92). Cheltenham: Edwards Elgar Publishing Limited. http://dx.doi.org/10.4337/9781782546344.00011.

Comi, A., \& Nuzzolo, A. (2016). Exploring the relationships between e-shopping attitudes and urban freight transport. Transportation Research Procedia, 12, 399-412. http://dx.doi.org/10.1016/j.trpro.2016.02.075.

Departamento Nacional de Trânsito - Denatran. (2018). Fleet: statistical reports. Retrieved in 2019, 4 March, from http://www.denatran.gov.br/estatistica

Deutsch, Y., \& Golany, B. (2017). A parcel locker network as a solution to the logistics last mile problem. International Journal of Production Research, 56(1-2), 251-261. http://dx.doi.org/10.1080/00207543.2017.1395490.

Ducret, R. (2014). Parcel deliveries and urban logistics: changes and challenges in the courier express and parcel sector in Europe - The French case. Research in Transportation Business \& Management, 11, 15-22. http://dx.doi.org/10.1016/j.rtbm.2014.06.009.

Durand, B., \& Gonzalez-Feliu, J. (2012). Urban logistics and e-grocery: have proximity delivery services a positive impact on shopping trips? Procedia: Social and Behavioral Sciences, 39, 510-520. http://dx.doi.org/10.1016/j.sbspro.2012.03.126.

E-bit. (2017). Webshoppers 36th edition 2017. Retrieved in 2019, 4 March, from https://www.ebit.com.br/webshoppers 
Edwards, J., McKinnon, A., Cherrett, T., McLeod, F., \& Song, L. (2010). Carbon dioxide benefits of using collectiondelivery points for failed home deliveries in the United Kingdom. Transportation Research Record: Journal of the Transportation Research Board, 2191(1), 136-143. http://dx.doi.org/10.3141/2191-17.

Ehmke, J. F., \& Campbell, A. M. (2014). Customer acceptance mechanisms for home deliveries in metropolitan areas. European Journal of Operational Research, 233(1), 193-207. http://dx.doi.org/10.1016/j.ejor.2013.08.028.

Esri. (2012). ArcGis 10.1 Help. Service Area and the Network Analyst. USA: Esri.

Garber, N. J., \& Hoel, L. A. (2014). Traffic and highway engineering. Toronto: CL Engineering.

González-Felíu, J., Ambrosini, C., \& Routhier, J. L. (2012). New trends on urban goods movement: modelling and simulation of e-commerce distribution. European Transport/Transporti Europei, 50, 1-23.

Guajardar, M., Zenezini, G., \& Montanaro, T. (2016). Home delivery services: innovations and emerging needs. IFAC-Papers online, 49(12), 1371-1376. https://doi.org/10.1016/j.ifacol.2016.07.755.

Instituto Brasileiro de Geografia e Estatistica - IBGE. (2010). Census. Rio de Janeiro: IBGE. Retrieved in 2019, 4 March, from https://censo2010.ibge.gov.br

Iwan, S., Kijewska, K., \& Lemke, J. (2016). Analysis of parcel lockers' efficiency as the last mile delivery solution the results of the research in Poland. Transportation Research Procedia, 12, 644-655.

http://dx.doi.org/10.1016/j.trpro.2016.02.018.

Junjie, X., \& Min, W. (2013). Convenient pickup point in e-commerce logistics : a theoretical framework for motivations and strategies. Computer Modelling \& New Technologies, 17(5C), 209-213.

Kedia, A., Kusumastuti, D., \& Nicholson, A. (2017). Acceptability of collection and delivery points from consumers' perspective: A qualitative case study of Christchurch city. Case Studies on Transport Policy, 5(4), 587-595. http://dx.doi.org/10.1016/j.cstp.2017.10.009.

KPMG International Cooperative. (2017). The truth about online consumers: 2017 global online consumer report. Amstelveen: KPMG. Retrieved in 2019, 4 March, from https://assets.kpmg.com/content/dam/kpmg/xx/pdf/2017/01/the-truth-about-online-consumers.pdf

Lachapelle, U., Burke, M., Brotherton, A., \& Leung, A. (2018). Parcel locker systems in a car dominant city: Location, characterisation and potential impacts on city planning and consumer travel access. Journal of Transport Geography, 71, 1-14. http://dx.doi.org/10.1016/j.jtrangeo.2018.06.022.

Langley, P., \& Iba, W. (1993). Avera-case analysis of a nearest neighbor algorithm. In Proceedings of the Thisteenth International Joint Conference on Artificial Inteligence (pp. 889-894). Chambery: IJCAI. https://doi.org/10.1.1.35.7011.

Lemke, J., Iwan, S., \& Korczak, J. (2016). Usability of the parcel lockers from the customer perspective - the research in Polish Cities. Transportation Research Procedia, 16, 272-287. http://dx.doi.org/10.1016/j.trpro.2016.11.027.

Liu, C., Wang, Q., \& Susilo, Y. O. (2019). Assessing the impacts of collection-delivery points to individual's activitytravel patterns: A greener last mile alternative? Transportation Research Part E, Logistics and Transportation Review, 121, 84-99. http://dx.doi.org/10.1016/j.tre.2017.08.007.

Lockie, W. (2014). Delivering an effective click-and-collect strategy: a retailer case study. Journal of Digital \& Social Media Marketing, 2(2), 139-152.

McLeod, F., Cherrett, T., \& Song, L. (2006). Transport impacts of local collection/delivery points. International Journal of Logistics Research and Applications, 9(3), 307-317. http://dx.doi.org/10.1080/13675560600859565.

Morganti, E., Dablanc, L., \& Fortin, F. (2014a). Final deliveries for online shopping: the deployment of pickup point networks in urban and suburban areas. Research in Transportation Business \& Management, 11, 23-31. http://dx.doi.org/10.1016/j.rtbm.2014.03.002.

Morganti, E., Seidel, S., Blanquart, C., Dablanc, L., \& Lenz, B. (2014b). The impact of e-commerce on final deliveries: alternative parcel delivery services in France and Germany. Transportation Research Procedia, 4, 178-190. http://dx.doi.org/10.1016/j.trpro.2014.11.014. 
Moroz, M., \& Polkowski, Z. (2016). The last mile issue and urban logistics: choosing parcel machines in the context of the ecological attitudes of the y generation consumers purchasing online. Transportation Research Procedia, 16, 378-393. http://dx.doi.org/10.1016/j.trpro.2016.11.036.

Newman, P., \& Kenwothy, J. (1999). Sustainability and cities: overcoming automobile dependence. Washington: Island Press.

Nuzzolo, A., \& Comi, A. (2014). A system of models to forecast the effects of demographic changes on urban shop restocking. Research in Transportation Business \& Management, 11, 142-151.

http://dx.doi.org/10.1016/j.rtbm.2014.03.001.

Oliveira, L. K., Morganti, E., Dablanc, L., \& Oliveira, R. L. M. (2017). Analysis of the potential demand of automated delivery stations for e-commerce deliveries in Belo Horizonte, Brazil. Research in Transportation Economics, 65, 34-43. http://dx.doi.org/10.1016/j.retrec.2017.09.003.

Oliveira, L. K., Nunes, N. T. R., \& Novaes, A. G. N. (2010). Assessing model for adoption of new logistical services: an application for small orders of goods distribution in Brazil. Procedia: Social and Behavioral Sciences, 2(3), 62866296. http://dx.doi.org/10.1016/j.sbspro.2010.04.038.

Song, L., Cherrett, T., McLeod, F., \& Guan, W. (2009). Addressing the last mile problem: transport impacts of collection and delivery points. Transportation Research Record: Journal of the Transportation Research Board, 2097(1), 9-18. http://dx.doi.org/10.3141/2097-02.

Song, L., Guan, W., Cherrett, T., \& Li, B. (2013). Quantifying the greenhouse gas emissions of local collection-anddelivery points for last-mile deliveries. Transportation Research Record: Journal of the Transportation Research Board, 2340(1), 66-73. http://dx.doi.org/10.3141/2340-08.

Vakulenko, Y., Hellström, D., \& Hjort, K. (2018). What's in the parcel locker? Exploring customer value in e-commerce last mile delivery. Journal of Business Research, 88, 421-427. http://dx.doi.org/10.1016/j.jbusres.2017.11.033.

van Duin, J. H. R., de Goffau, W., Wiegmans, B., Tavasszy, L. A., \& Saes, M. (2016). Improving home delivery efficiency by using principles of address intelligence for B2C deliveries. Transportation Research Procedia, 12, 1425. http://dx.doi.org/10.1016/j.trpro.2016.02.006.

Visser, J., Nemoto, T., \& Browne, M. (2014). Home delivery and the impacts on urban freight transport: a review. Procedia: Social and Behavioral Sciences, 125, 15-27. http://dx.doi.org/10.1016/j.sbspro.2014.01.1452.

Wang, X., Yuen, K. F., Wong, Y. D., \& Teo, C. C. (2018). An innovation diffusion perspective of e-consumers' initial adoption of self-collection service via automated parcel station. International Journal of Logistics Management, 29(1), 237-260. http://dx.doi.org/10.1108/IJLM-12-2016-0302.

Xiao, S., Wang, J. J., \& Liu, Q. (2018). The impacts of final delivery solutions on e-shopping usage behaviour: the case of Shenzhen, China. International Journal of Retail \& Distribution Management, 46(1), 2-20.

http://dx.doi.org/10.1108/IJRDM-03-2016-0036.

Xu, J., Hong, L., Li, Y. (2011). Designing of collection and delivery point for E-commerce logistics. In International Conference of Information Technology, Computer Engineering and Management Sciences (pp. 349-352). USA: IEEE.

Yuen, K. F., Wang, X., Ng, L. T. W., \& Wong, Y. D. (2018). An investigation of customers' intention to use self-collection services for last-mile delivery. Transport Policy, 66, 1-8. http://dx.doi.org/10.1016/j.tranpol.2018.03.001.

Editor: Janaina Pasqual Lofhagen.

Received: Mar. 04, 2019

Approved: Apr. 16, 2019 